\title{
The Ctenodactylidae (Rodentia) in northern Africa and a new location record for Pectinator spekei Blyth, 1856 in Afar Na- tional Regional State, Ethiopia
}

\author{
R.Trevor Wilson
}

Bartridge Partners, Bartridge House, Umberleigh, UK, EX37 9AS; e-mail: trevorbart@aol.com

\begin{abstract}
The Ctenodactylidae is a small family of rodents comprising only five species in four genera. Four of the species are confined to North Africa in Mauritania, Morocco, Algeria, Tunisia, Libya, Senegal, Mali, Chad, and Niger. The fifth, Pectinator spekei, is the only one of the family that is found in the northeastern Horn of Africa. Earlier records have shown its presence in Somalia, Djibouti, Eritrea and eastern Ethiopia at altitudes below 1,200 meters. Sightings of this species in early November 2018 were at $13^{\circ} 17^{\prime} 47.7^{\prime \prime} \mathrm{N}, 39^{\circ} 49^{\prime} 32.8^{\prime \prime} \mathrm{E}$ at an altitude of 1,560 meters. This location is more than $300 \mathrm{~km}$ horizontally and almost 400 meters vertically from previous records. The IUCN Red List classification of least concern is strengthened by this new record in an area little disturbed by humans.
\end{abstract}

KEY WORDS Biogeography; IUCN Red List; least concern; range extension; rodents.

Received 19.02.2019; accepted 02.03.2019; published online 20.03.2019

\section{INTRODUCTION}

The Ctenodactylidae Gervais, 1853 (Greek: "comb-toe") is a unique family in the suborder Sciuravida of the order Rodentia. The family, whose members are sometimes known as "gundis", comprises five extant species in four genera, but 16 extinct genera are known from fossils from Africa, Sicily (Italy), and parts of Asia. The family has no close relatives among current rodents and is a small relict cluster of evolutionary diversification that began in the Early Eocene from 54.8 to 49.0 million years ago (López-Antoñanzas \& Knoll, 2011). These terrestrial animals inhabit rocky and sparsely vegetated areas that are characterized by low humidity and long sunny days.

All five extant species inhabit Africa north of the equator, four in Saharan regions of northern Africa and one - the main subject of this paper - in the Horn of Africa (López-Antoñanzas, 2016).
The first described of the extant species is Ctenodactylus gundi (Rothmann, 1776). This species is found in a narrow band from southeast of Fez in Morocco across Algeria and Tunisia to the West of Tripoli in Libya at altitudes ranging from 230 to 2900 meters. A part of this tract is included in protected areas and the species is classed as of least concern by IUCN (Aulagnier, 2008).

Massoutiera mzabi (Lataste, 1881) occupies the most desertic areas of the family, in the central Sahara regions of Algeria (Tassili n'Ajiers, Hoggar, Tefedest and Mouydir) and around the plateau of Tademait and the Mzab Valley, whence it is named (Gouat et al., 2009). It is also present in northeastern Mali, northern Niger, northwestern Chad and probably in Libya (Cassola, 2016a). The "Mzab gundi" occurs at elevations of 500-2,500 metres, is present in several protected areas and is classified as of least concern by IUCN (Cassola, 2016a). The most southerly of the Saharan species is Felovia vae 
Lataste, 1886, classified by IUCN as of least concern (Gerrie et al., 2017). This "Felou Gundi" occurs through much of central and southern Mauritania with small extensions into northwestern Mali and possibly into eastern Senegal (Gerrie et al., 2017) and has been described as a mountain specialist (Brito et al., 2010). The fourth and most recently described of the Saharan species is Ctenodactylus vali Thomas 1902, sometimes known as "Val's Gundi". Ctenodactylus vali occurs in two isolated populations: the one astride the Morocco/Algeria boundary to the East of Marrakech, the other in a small area of Libya to the South of Tripoli (Gerrie \& Kennerley, 2016). Relatively little is known of this species and it is classified by IUCN as data deficient (Gerrie \& Kennerley, 2016).

The only member of the Ctenodactylidae that is not found in the Saharan area is Pectinator spekei Blyth, 1856. The type locality of "Speke's Gundi" is in Somalia between Las Koreh and the Nogal valley ( $\left.09^{\circ} \mathrm{N} ; 47^{\circ} \mathrm{E}\right)$ - now in Puntland State of northeastern Somalia - but its distribution in Somalia is unclear. Elsewhere, the species has been recorded from Djibouti, Eritrea and Ethiopia. Most early records were from what is now Djibouti in the Tadjoura Bay and Obock areas at about $12^{\circ} \mathrm{N} ; 43^{\circ} \mathrm{E}$ and from around Assab at about $13^{\circ} \mathrm{N} ; 43^{\circ} \mathrm{E}$ (now in Eritrea but originally part of Ethiopia). Later records made by Dr W George of Lady Margaret Hall, Oxford University, probably in the early 1970s, are from the lowland area of the extreme east of Ethiopia in an area bounded by $9^{\circ}$ to $12^{\circ} \mathrm{N}$ and $41^{\circ}$ to $42^{\circ} \mathrm{E}$ (Yalden et al., 1976: 61). A recent study has again recorded P. spekei in Djibouti in an area of sand and rocks with low scrub and some trees (Pearch et al., 2002).

A checklist of Ethiopian mammals give the zoogeographic region of SA (= Somali-arid) as the habitat of the species at altitudes of sea level to 1200 metres with a suggestion (without supporting evidence, of a possible altitudinal upper limit of 2200 metres (Yalden et al., 1996). It is recorded that this species is an inhabitant of rocky cliffs (sheltering in rock fissures) in desert or semi-desert areas and that it is sometimes found in association with hyraxes (Yalden et al., 1976).

Following Yalden et al. (1976), this species is characterized by: "The short, well-furred tail and stiff white bristles covering the claws are probably sufficient to distinguish this species, which looks superficially like a small ground squirrel".

\section{RESULTS AND CONCLUSIONS}

Several animals conforming to this description (Yalden et al., 1976) were seen basking and moving about on rocks at 16:23 hours East African Time (GMT +3) on 5 November 2018 (Fig. 1, Fig. 2). The location at $13^{\circ} 17^{\prime} 47.7^{\prime \prime} \mathrm{N}, 39^{\circ} 49^{\prime} 32.8^{\prime \prime} \mathrm{E}$ (Fig. 3) at an altitude of $1,560 \mathrm{~m}$ on the wall of the rift valley is $10 \mathrm{~km}$ circa South of the District Administrative centre at Abala (also known as Shiket) in Afar Region and about $3 \mathrm{~km}$ East of the AfarTigray regional boundary. The vegetation here has been described as sub-desert scrub growing on shallow soils over limestone parent material. At this particular site, described in detail in 1974, 32 species of trees and shrubs were identified with three species of Commiphora being dominant (24\%), followed by Acacia mellifera (18\%), Grewia erythraea (12\%), and Grewia mollis (9\%) (Wilson, 1977). In November 2018 the vegetative composition, with a very sparse field layer of grasses and herbs among rock outcrops had superficially not changed from the assessment of 1974 (Fig. 4).

This new location record for Pectinator spekei represents considerable horizontal and vertical range extensions compared to earlier records. It is $310 \mathrm{~km}$ West and $47 \mathrm{~km}$ North of earlier Assab records and $322 \mathrm{~km}$ and $185 \mathrm{~km}$ North of the cluster of records listed by Dr George (Yalden et al., 1976). At an elevation of 1,560 metres above sea level this new site is almost 400 metres higher than previously accepted elevations.

IUCN lists the species as being of least concern (Cassola, 2016b). This classification results from its relatively wide distribution, a presumed large overall population and a lack of significant threats. In this range extension area there is no human-induced habitat loss (the area is very lightly used for feeding for mainly camels and goats), there is no persecution by local people and the observed population structure (although of small numbers) shows a mix of mature and young animals. These facts serve to reinforce the IUCN classification of $P$. spekei being of least concern. 


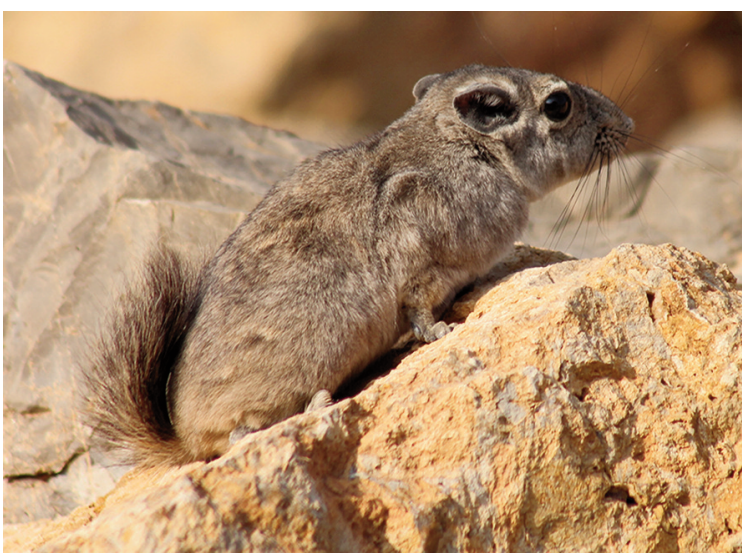

Figure 1. Adult Pectinator spekei basking on rock surface showing short bushy tail.

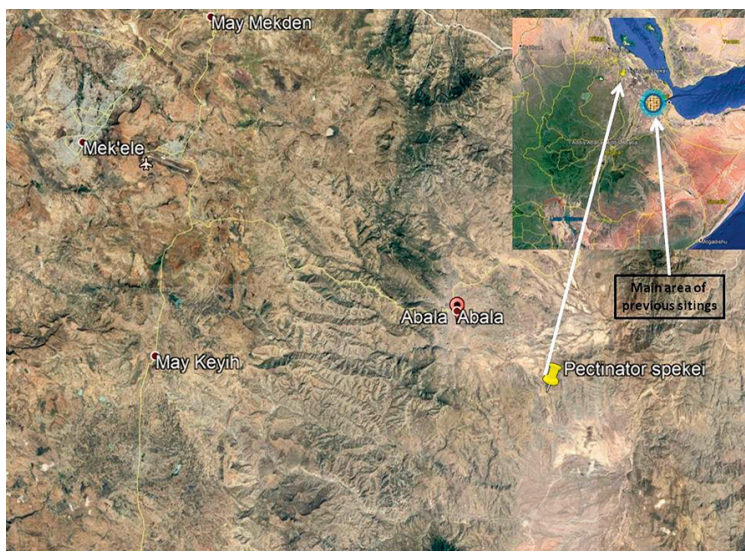

Figure 3. Location of sighting of Pectinator spekei in Afar Regional State, Ethiopia: detail of area of observation; in context of Ethiopia; and, main area of previous observations.

\section{REFERENCES}

Aulagnier S., 2008. Ctenodactylus gundi. The IUCN Red List of Threatened Species, 2008: e.T5792A117 01789. https://doi.org/10.2305/IUCN.UK.2008. RLTS. T5792 A11701789.en. Downloaded on 07 December 2018.

Brito J.C., Álvares F., Martínez-Freiría F., Sierra P., Sillero N. \& Parroso P., 2010. Ctenodactylus gundi. Data on the distribution of mammals from Mauritania, West Africa. Mammalia, 74: 449-455. https:// doi.org/10.1515/MAMM.2010.055.

Cassola F,. 2016a. Massoutiera mzabi. The IUCN Red List of Threatened Species, 2016: e.T12855 A22191 765. https://doi.org/10.2305/IUCN.UK.2016-2.RLTS. T12855A22191765.en. Downloaded on 13 December 2018 .

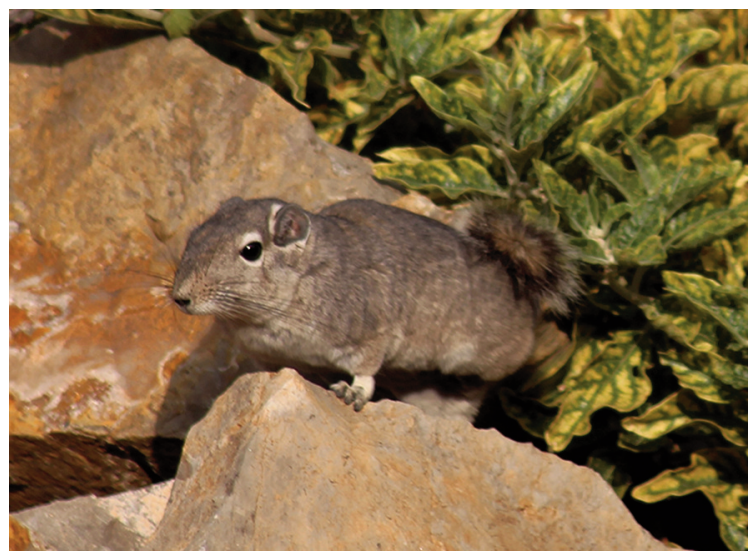

Figure 2. Attentive adult Pectinator spekei close to entrance to rock burrow.

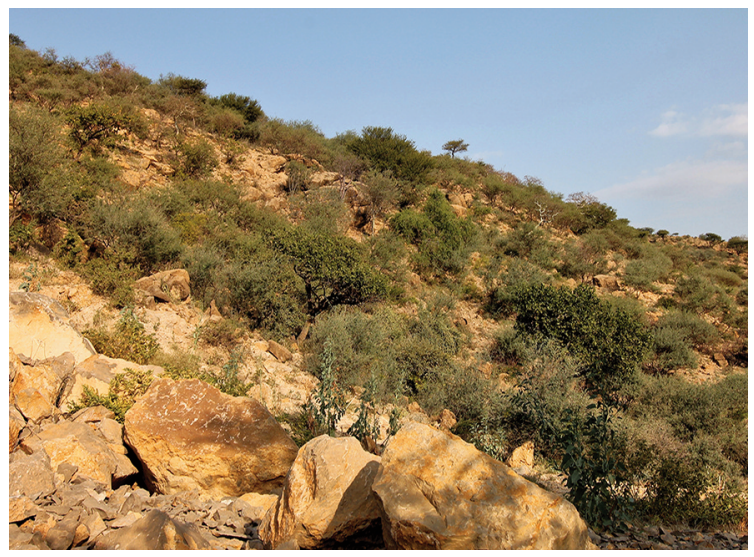

Figure 4. Rock outcrop populated by rodents set in context of semi-desert scrub in Afar National Regional State, Ethiopia.

Cassola F., 2016b. Pectinator spekei (errata version published in 2017). The IUCN Red List of ThreatenedSpecie,2016: e.T16458A115133455.http://dx. doi.org/10.2305/ IUCN.UK.20163.RLTS.T16458A 22191688.en. Downloaded on 27 November 2018.

Gerrie R. \& Kennerley R., 2016. Ctenodactylus vali (errata version published in 2017). The IUCN Red List of Threatened Species, 2016: e.T5793A115518270. https://doi.org/10.2305/IUCN.UK.2016-3. RLTS.T5793A102029922.en. Downloaded on 07 December 2018.

Gerrie R., Kennerley R. \& Granjon L., 2017. Felovia vae. The IUCN Red List of Threatened Species, 2017: e.T8548A22191482. https://doi.org/10.2305/ IUCN. UK.20172.RLTS.T8548A22191482.en. Downloaded on 13 December 2018.

Gouat P., Gouat J. \& Coulon J., 2009. Répartition et habi- 
tat de Massoutiera mzabi (Rongeur Cténodactylidé) en Algérie. Mammalia, 48: 351-362. https://doi.org/ 10.1515/ mamm.1984.48 .3.351.

López-Antoñanzas R., 2016. Ctenodactylidae (gundis). In: Wilson D.E., Lacher Jr. T.E. \& Mittermeier R.A., 2016. Handbook of the Mammals of the World, Volume 6, Lagomorphs \& Rodents I., Lynx Edicions, Barcelona. 173-184.

López-Antoñanzas R. \& Knoll F., 2011. A comprehensive phylogeny of the gundis (Ctenodactylinae, Ctenodactylidae, Rodentia). Journal of Systematic Palaeontology, 9: 379-398. https://doi.org/10. 1080/ 14772019.2010 .529175$.

Pearch M.J., Bates P.J.J. \& Magin C., 2002. A review of the small mammal fauna of Djibouti and the results of a recent survey, Mammalia, 65: 387-410. https:// doi.org/10.1515/mamm.2001.65.3.387.

Wilson R.T., 1977. The vegetation of central Tigré, Ethiopia, in relation to its land use. Webia 32: 235270. https://doi.org/10.1080/00837792.1977.106 70095.

Yalden D.W., Largen M.J. \& Kock D., 1976. Catalogue of the mammals of Ethiopia, 2. Insectivora and Rodentia. Monitore Zoologico Italiano Supplemento, 8: 1, 1- 118. https://doi.org/10.1080/03749444.1976. 10736830.

Yalden D.W., Largen M.J., Kock D. \& Hillman J.C., 1996. Catalogue of the Mammals of Ethiopia and Eritrea ,7. Revised checklist, zoogeography and conservation. Tropical Zoology, 9: 73-164. https://doi. org/10.1080/03946975.1996. 10539304. 